\title{
Dormancy-breaking treatments and soil types on Chamaecrista rotundifolia emergence and initial development
}

\section{Tratamentos de superação de dormência e tipos de solo na emergência e desenvolvimento inicial de Chamaecrista rotundifolia}

Josilene do Nascimento Gomes ${ }^{1}\left[\mathbb{0}\right.$, Natan Lima Abreu ${ }^{1 *}(\mathbb{0}$, Angélica Lucélia da Silva

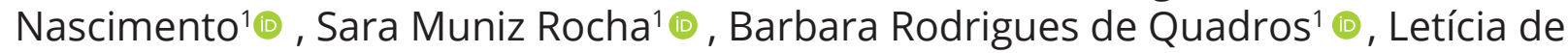
Abreu Faria ${ }^{1}$ (i)

${ }^{1}$ Universidade Federal Rural da Amazônia, Belém, PA, Brazil

*Correspondent - natanlima17121997@gmail.com

Received

November 17, 2020

Accepted

December 4, 2020

Published

March xx, 2021

www.revistas.ufg.br/vet visit the website to get the how to cite in the article page.

\begin{abstract}
Chamaecrista rotundifolia is a legume of high yield and nutritional value for livestock; however, it presents high seed dormancy. The aim of this study was to evaluate dormancybreaking methods and the influence of soil texture on seedling emergence and initial development of $C$. rotundifolia. The experiment was performed in a greenhouse in a split-plot design with five replications. There were three treatments including dormancy-breaking techniques with immersion of the seeds in (1) hot water at $80^{\circ} \mathrm{C}$ for $30 \mathrm{~s}$ followed by $12 \mathrm{~h}$ in water at room temperature $\left(25^{\circ} \mathrm{C}\right.$; HW); (2) water at room temperature $\left(25^{\circ} \mathrm{C}\right)$ for $24 \mathrm{~h}(\mathrm{EW})$; and (3) hydrochloric acid (0.05 mol L-1) for 15 min (HA) (4) and a control group with no seed intervention, disposed in the main plots in randomized blocks. Seeds were cropped in two types of soil as subplots. Seedling emergence was evaluated daily to calculate the percentage emergence and emergence speed index. Plant performance was evaluated (21 days after sowing) through measurements of mass and length of components. Chamaecrista rotundifolia showed a high degree of dormancy in the seeds, and the treatment using HW had greater efficiency in seedling emergence $(p<0.01)$ and emergence speed index $(p<0.05)$. Total dry mass was superior in sandy soil $(p<0.05)$. Soil texture and dormancy treatments influenced the initial performance of plants, which performed better in sandy soil. Key words: germination; legume; sandy; seed; soil texture.
\end{abstract}

\section{Resumo}

A Chamaecrista rotundifolia é uma leguminosa com alto valor nutritivo e boa produção para a pecuária, no entanto apresenta elevada dormência em suas sementes. O objetivo foi avaliar métodos de superação de dormência e a influência da textura do solo na emergência das plântulas e desempenho inicial. O experimento foi realizado em casa de vegetação em delineamento com parcelas subdivididas e cinco repetições. Os tratamentos consistiram em técnicas de superação de dormência com a imersão das sementes em (1) água quente a 
$80^{\circ} \mathrm{C}$ por $30 \mathrm{~s}$ seguida pela imersão em água a temperatura ambiente por $12 \mathrm{~h}$; (2) imersão em água a temperatura ambiente $\left(25^{\circ} \mathrm{C}\right)$ por $24 \mathrm{~h}$ e (3) imersão em ácido clorídrico $\left(0,05 \mathrm{~mol} \mathrm{~L}^{-1}\right)$ por $15 \mathrm{~min}$, e um grupo controle (sem intervenção nas sementes), dispostos nas parcelas em blocos casualizados. As sementes foram cultivadas em dois solos como subparcelas. Foi avaliada a emergência diária das mudas para calcular o percentual e o índice de velocidade de emergência. Aos 21 dias após a semeadura, o desempenho da planta foi avaliado por meio de medidas e massa dos componentes. O tratamento com água quente apresenta maior eficiência em promover a emergência de plântulas $(p<0,01)$ e no índice de velocidade de emergência $(p<0,05)$. O total de massa seca se destacou em solo arenoso $(p<0,05)$. A textura do solo influencia os tratamentos de superação de dormência nos parâmetros de desempenho inicial das plantas, sendo observado melhor desempenho em solo arenoso.

Palavras-chave: germinação; leguminosa; arenoso, semente; textura de solo.

\section{Introduction}

Legume forages are a low-cost form of nitrogen introduction to pastures, improving soil fertility and animal development ${ }^{(1)}$. Chamaecrista (Chamaecrista rotundifolia (Pers.) Greene var. rotundifolia) is among many tropical legumes (Fabaceae) in Brazil. This species was improved in Australia, and currently, it is promising for intercropping in tropical pastures ${ }^{(2)}$ as well as an exclusive crop with yield and suitable chemical composition for hay production ${ }^{(3)}$.

Knowledge about C. rotundifolia in agriculturally productive environments is still being established through studies in the Amazon region. Moreover, there are some challenges for the establishment of this species as forage in tropical pastures in Brazil, as the seeds are commercially unavailable ${ }^{(4)}$ and present dormancy ${ }^{(5)}$.

Tegmental dormancy is common in Fabaceae(6). Tegument is recognized as a seed protector against temperature fluctuations, humidity, and microorganism infection ${ }^{(7)}$. However, the low capacity of water absorption of these seeds blocks the imbibition process, hindering embryo growth and, consequently, delaying germination and plant emergence $^{(8)}$.

Delay in seed germination and seedling emergence generates inequality in crops, which is detrimental to agricultural production. According to Gautam et al.(9), rapid, uniform, and complete emergence leads to vigorous seedlings with high yield potential by shortening the time from sowing to complete ground cover, thus allowing the establishment of an optimum canopy structure to minimize interplant competition and maximize crop yield.

In this context, seed dormancy is an undesirable characteristic for productive environments. For seed with integumentary dormancy, tegument rupture is necessary, 
allowing water absorption and metabolic activities to restart germination ${ }^{(6)}$. Nevertheless, germination delays caused by seed tegument may be overcome using techniques that vary from species to species. Nevertheless, techniques to break seed dormancy should be accessible to farmers.

Seedling emergence and plant initial development can also be influenced by sowing depth and available moisture as well as soil characteristics such as texture or fertility. Cruz et al.(2) reported C. rotundifolia preference for sandy soils; however, high yield on clayey soil was obtained by Abreu et al.(3).

Research on techniques to dormancy-breaking in C. rotundifolia aim to improve the plant's establishment stimulating the species diffusion, and use it as forage in tropical environments. The aims of this study were to evaluate the methods to break C. rotundifolia dormancy and the influence of soil texture on the emergence and initial development of this species seedlings.

\section{Materials and Methods}

The research was performed in a greenhouse at the Universidade Federal Rural da

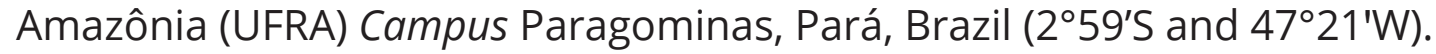

Chamaecrista rotundifolia seeds were obtained from pods harvested on a pasture area when these presented a dark (brown to black) color. Afterwards, pods were exposed to sunlight covered by cotton tissue to avoid seed losses during disruption of pods. Seeds were collected and maintained in brown paper bags until use; then, seeds were manually selected according to color and size, excluding damaged seeds.

Experimental soils were classified as frank sandy, according to contents of $11.9 \%, 10.6 \%$, and $77.5 \%$ clay, silt, and clay and, very clayey texture, according to contents of $77.4 \%$, $12.6 \%$, and $10.0 \%$ clay, silt, and clay, whereas, chemical parameters of soil fertility are shown in Table 1.

Table 1. Characterization of chemical parameters of soil fertility in the $0-20-\mathrm{cm}$ depth layer

\begin{tabular}{|c|c|c|c|c|c|c|c|c|c|}
\hline \multirow{2}{*}{ Soils } & pH & P resin & S & K & $\mathrm{Ca}$ & $\mathrm{Mg}$ & $\mathrm{H}+\mathrm{Al}$ & CEC & \multirow{2}{*}{$\begin{array}{c}\text { O.M. } \\
\mathrm{g} \mathrm{dm}^{-3}\end{array}$} \\
\hline & $\mathrm{CaCl}_{2}$ & \multicolumn{2}{|c|}{$\mathrm{mg} \mathrm{dm}^{-3}$} & \multicolumn{4}{|c|}{$\mathrm{mmol} \mathrm{dm}^{-3}$} & & \\
\hline Sandy & 4.6 & 10.7 & 59.9 & 1.6 & 8.9 & 5.3 & 25.0 & 40.8 & 19.9 \\
\hline Clayey & 5.6 & 12.0 & 28.0 & 4.2 & 39.0 & 9.0 & 22.0 & 42.8 & 30.0 \\
\hline
\end{tabular}

The experiment was performed on a split-plot design with five replications. The treatments comprised three dormancy-breaking techniques and a control group (with no seed intervention), disposed in the main plots in randomized blocks and two soil types in subplots.

Seeds were immersed in different solutions, comprising the dormancy-breaking treatments: seeds were immersed in (1) hot water $\left(80^{\circ} \mathrm{C}\right)$ for $30 \mathrm{~s}$ and in room- 
temperature water $\left(25^{\circ} \mathrm{C}\right)$ for $12 \mathrm{~h}(\mathrm{HW}) ;(2)$ room-temperature water $\left(25^{\circ} \mathrm{C}\right)$ for $24 \mathrm{~h}$ (EW); (3) hydrochloric acid $\left(0.05 \mathrm{~mol} \mathrm{~L}^{-1}\right)$ for $15 \mathrm{~min}(\mathrm{HA})$ and was included a (4) control group (with no seed intervention). All seeds were cultivated in two soil types, sandy and clayey.

The experimental unit representing a plot consisted of a circular plastic container $(\varnothing$ $25 \mathrm{~cm}$ ) containing a plate of Styrofoam in the middle, dividing the container in two subplots, each filled with $2 \mathrm{~kg}$ of sandy or clayey air-dried, sieved soil. In each subplot, 25 seeds were planted $0.5 \mathrm{~cm}$-deep. Plots were organized in blocks, according to their positions in the greenhouse. The soil was moistened with $60 \%$ water-holding capacity during the experimental period. Seedling emergence was evaluated daily between 8 and 9 AM until the removal of plants ( $21 \mathrm{~d}$ after sowing). Plant roots were cleaned using running water and dried with paper towels for fresh weight and length measurements. Subsequently, plants were placed in a forced air oven at $65^{\circ} \mathrm{C}$ for $72 \mathrm{~h}$ to determine the dry mass content.

Data of percentage emergence were calculated using the formula proposed by Labouriau et al.(10); the emergency speed index was determined using observations of daily emerged seedlings adjusted by the formula from Maguire(11).

Experimental data were analyzed using the statistical program SAS 9.4 (Statistical Analysis System Institute, Cary NC, USA). Analysis of variance (ANOVA) was performed; if difference among treatments was determined, means were compared using Tukey's test at $5 \%$ of probability. Dormancy-breaking and control treatments as well as the soil types, were considered fixed effects according to the following mathematical model:

$$
y i j k=\mu+\tau i+y k+e i k+\beta j+(\tau \beta) i j+\epsilon i j k
$$

yijk is value observed; $\mu$, the experimental mean; $\tau i$, main plot treatment effect (dormancy-breaking treatments); yk, block effect; eik, plot residue; $\beta \mathrm{j}$, effect of subplots (soil types); ( $\tau \beta) i j$, the main plot and subplot treatment interaction effect; and $\in$ ijk is the subplot residue.

\section{Results}

Dormancy-breaking treatments influenced the emergence and initial development of C. rotundifolia. There was no effect of the interaction between soil types and dormancybreaking treatments ( $p>0.05$ ) on parameters of seedling emergence and emergence speed index. Control group and dormancy-breaking treatments were statistically similar, except hot water treatment for seedling emergence $(p<0.01)$ and emergence speed index $(p<0.05)$ (Table 2$)$.

Seedling percentage emergence in the HW treatment was 171.9\% $(p<0.01)$ higher than that in control, and $356.8 \%$ for emergence speed index $(p<0.05)$.

Soil types showed no effect on the emergence parameters ( $p>0.05$ ). There was 19.5\% and $17.7 \%$ of seedling emergence in the sandy and clayey soils, respectively. For the emergence speed index, the soil types showed values of $7.8 \%$ and $6.2 \%$ for sandy and clayey soils, respectively. 
Dormancy-breaking treatments showed no effect on most plant production parameters $(p>0.05)$, except for seeds treated with HW or HA, which showed higher aerial dry mass content than those of other treatments in sandy soil (Table 3).

Table 2. Seedling emergence (EME) and emergence speed index (ESI) for dormancy-breaking treatments

\begin{tabular}{lcc}
\hline Treatment & EME (\%) & ESI \\
\hline $\mathrm{C}$ & $16.0 \mathrm{bc}$ & $3.7 \mathrm{~b}$ \\
$\mathrm{EW}$ & $20.8 \mathrm{ab}$ & $5.7 \mathrm{~b}$ \\
$\mathrm{HW}$ & $27.5 \mathrm{a}$ & $13.2 \mathrm{a}$ \\
$\mathrm{HA}$ & $9.9 \mathrm{c}$ & $5.5 \mathrm{ba}$ \\
\hline $\mathrm{CV}(\%)$ & 49.1 & 84.3 \\
\hline
\end{tabular}

$\mathrm{C}=$ Control group; $\mathrm{EW}=$ seed immersion in room-temperature water $\left(25^{\circ} \mathrm{C}\right)$ for $24 \mathrm{~h} ; \mathrm{HW}=$ seed immersion in hot water $\left(80^{\circ} \mathrm{C}\right)$ for $30 \mathrm{~s}$ followed by immersion in room-temperature water $\left(25^{\circ} \mathrm{C}\right)$ for $12 \mathrm{~h}$; HA = seed immersion in hydrochloric acid $\left(0.05 \mathrm{~mol} \mathrm{~L}^{-1}\right)$ for $15 \mathrm{~min} . \mathrm{CV}=$ coefficient of variation. Means with different letters on the same column differ significantly, according to Tukey's Test $(p<0.05)$.

Table 3. Fresh aerial mass (FAM), fresh root mass (FRM), total fresh mass (TFM), dry root mass (DRM), and total dry mass (TDM) of plants from dormancy-breaking treatments, and the effect of the interaction with soils types on dry aerial mass (DAM)

\begin{tabular}{|c|c|c|c|c|c|}
\hline Treatment & FAM & FRM & TFM & DRM & TDM \\
\hline $\mathrm{C}$ & $0.079 a$ & $0.008 a$ & $0.087 a$ & $0.008 a$ & $0.047 a$ \\
\hline EW & $0.065 a$ & $0.004 a$ & $0.069 a$ & $0.001 \mathrm{a}$ & $0.049 a$ \\
\hline HW & $0.125 a$ & $0.008 a$ & $0.134 a$ & $0.005 a$ & $0.059 a$ \\
\hline $\mathrm{HA}$ & $0.077 a$ & $0.007 a$ & $0.084 a$ & $0.003 a$ & $0.043 a$ \\
\hline \multirow[t]{2}{*}{ CV (\%) } & 87.06 & 94.17 & 82.36 & 200.09 & 98.06 \\
\hline & \multicolumn{5}{|c|}{ DAM } \\
\hline \multirow[t]{2}{*}{ Soils } & $\mathrm{C}$ & EW & HW & HA & \multirow{2}{*}{ CV (\%) } \\
\hline & & & g & & \\
\hline Sandy & $0.025 \mathrm{Ba}$ & $0.058 \mathrm{ABa}$ & $0.079 \mathrm{Aa}$ & $0.066 \mathrm{ABa}$ & \multirow{2}{*}{85.35} \\
\hline Clayey & $0.052 \mathrm{Aa}$ & $0.014 \mathrm{Aa}$ & $0.029 \mathrm{Ab}$ & $0.012 \mathrm{Ab}$ & \\
\hline
\end{tabular}

$\mathrm{C}=\mathrm{Control}$; $\mathrm{EW}=$ seed immersion in room-temperature water $\left(25^{\circ} \mathrm{C}\right)$ for $24 \mathrm{~h}$; HW $=$ seed immersion in hot water $\left(80^{\circ} \mathrm{C}\right)$ for $30 \mathrm{~s}$ followed by seed immersion in room-temperature water $\left(25^{\circ} \mathrm{C}\right)$ for $12 \mathrm{~h}$; $\mathrm{HA}=$ seed immersion in hydrochloric acid $\left(0.05 \mathrm{~mol} \mathrm{~L}^{-1}\right)$ for $15 \mathrm{~min} ; \mathrm{CV}=$ coefficient of variation; Means followed by different small letters in the same column or capital letters in the same line differ significantly according to Tukey's test $(p<0.05)$. 
Both soil types showed high fertility standards (Table 1), but C. rotundifolia showed a preference for sandy soil for its initial development, based on the superior results of fresh aerial mass $(p<0.05)$, total fresh mass $(p<0.01)$, and total dry mass $(p<0.01)$. However, the mass of roots, fresh or dry, were similar ( $p>0.05)$ (Table 4).

Table 4. Fresh aerial mass (FAM), fresh root mass (FRM), dry root mass (DRM), total fresh mass (TFM), and total dry mass (TDM) for different soils

\begin{tabular}{llllll}
\hline \multirow{2}{*}{ Soil type } & FAM & FRM & DRM & TFM & TDM \\
\cline { 2 - 6 } & \multicolumn{5}{c}{$\mathbf{g}$} \\
\hline Sandy & $0.119 \mathrm{a}$ & $0.008 \mathrm{a}$ & $0.006 \mathrm{a}$ & $0.127 \mathrm{a}$ & $0.069 \mathrm{a}$ \\
Clayey & $0.054 \mathrm{~b}$ & $0.006 \mathrm{a}$ & $0.003 \mathrm{a}$ & $0.060 \mathrm{~b}$ & $0.030 \mathrm{~b}$ \\
\hline $\mathrm{CV}(\%)$ & 87.06 & 94.17 & 200.09 & 82.36 & 98.06 \\
\hline CV = coefficient of variation; $\mathrm{ns}=$ not significant; Different letters on the same column differ \\
significantly, according to Tukey's test ( $\mathrm{p}<0.05)$.
\end{tabular}

Interaction of dormancy-breaking and soil treatments showed effects on the length parameters of $C$. rotundifolia plants $(p<0.05)$. HW had a positive influence on plant total and aerial length on sandy soil, which was not verified for plants in the clayey soil (Table 5).

Table 5. Total length (TL), root length (RL), and length of the aerial part (AL) of Chamaecrista rotundifolia submitted to treatments for seed dormancy breaking

\begin{tabular}{|c|c|c|c|c|}
\hline Soil type & Treatment & TL & $\mathbf{R L}$ & $A L$ \\
\hline \multirow{4}{*}{ Sandy } & $C$ & $9.68 \mathrm{bB}$ & $5.10 \mathrm{aB}$ & $4.58 \mathrm{CA}$ \\
\hline & EW & $14.86 \mathrm{abA}$ & $7.36 \mathrm{aA}$ & $7.52 \mathrm{bcA}$ \\
\hline & HW & $16.88 \mathrm{aA}$ & $8.32 \mathrm{aA}$ & $8.54 a b A$ \\
\hline & $\mathrm{HA}$ & $15.48 \mathrm{abA}$ & $7.70 \mathrm{aA}$ & $7.77 \mathrm{bA}$ \\
\hline \multirow{4}{*}{ Clayey } & C & $15.82 \mathrm{aA}$ & $8.54 \mathrm{aA}$ & $7.28 \mathrm{aA}$ \\
\hline & EW & $12.02 \mathrm{abA}$ & $6.50 \mathrm{abA}$ & $5.52 \mathrm{abA}$ \\
\hline & $\mathrm{HW}$ & $13.50 \mathrm{abA}$ & $7.60 \mathrm{abA}$ & $5.90 \mathrm{abA}$ \\
\hline & $\mathrm{HA}$ & $8.60 \mathrm{bB}$ & $4.80 \mathrm{bA}$ & $3.80 \mathrm{bB}$ \\
\hline CV (\%) & & 33.20 & 34.07 & 36.65 \\
\hline \multicolumn{5}{|c|}{$\begin{array}{l}\mathrm{C}=\text { Control group; EW = seed immersion in room-temperature water }\left(25^{\circ} \mathrm{C}\right) \text { for } 24 \mathrm{~h} \text {; HW = seed } \\
\text { immersion in hot water }\left(80^{\circ} \mathrm{C}\right) \text { for } 30 \mathrm{~s} \text { followed by seed immersion in room-temperature water } \\
\left(25^{\circ} \mathrm{C}\right) \text { for } 12 \mathrm{~h} ; \mathrm{HA}=\text { seed immersion in hydrochloric acid }\left(0.05 \mathrm{~mol} \mathrm{~L}^{-1}\right) \text { for } 15 \mathrm{~min} \text {; } \mathrm{CV}=\text { coefficient } \\
\text { of variation; Means followed by different small letters on column for soil differ among treatments } \\
\text { for seed dormancy breaking or capital letter on column differ soils for each treatments for seed } \\
\text { dormancy breaking significatively to } \mathrm{p}<0.05 \text { of probability by Tukey test } \\
\text { according to Tukey's test }(\mathrm{p}<0.05) \text {. }\end{array}$} \\
\hline
\end{tabular}


In addition, the lower effect of HA on seedling emergence than that of other treatments (Table 2) reflected on plant length parameters, mostly on clayey soil (Table 5).

\section{Discussion}

Chamaecrista rotundifolia seed dormancy could be verified in this study through the low emergence of seedling in the control group and the increased emergence in other treatments (Table 2), corroborating the findings of Lima et al. (5) through the germination data. The low seedling emergence, especially in the control group, was possibly due to the low germination index associated with dormancy.

In this context, our results for percentage emergence are similar to those observed by Lima et al. ${ }^{(5)}$, in which there was $14 \%$ germination of $C$. rotundifolia seeds in a lab-controlled environment. These similarities could point to low soil influence on germination, confirmed by the absence of effects of soil, or its interaction, on treatments of dormancy-breaking.

According to Ribeiro et al. ${ }^{(12)}$, substrate characteristics can influence seedling emergence; however, soil effects on seedling emergence and emergence speed index could be explained by the humidity control and superficial sowing of $C$. rotundifolia.

Another factor could also affect the germination, as seedling emergence was low and highly variable (high values of coefficient of variation) even in dormancy-breaking treatments (Table 2), which is the variable maturity stage of the seeds on the same pod, as is common in legumes.

A concern about this species is that seeds are usually collected before their natural dispersal. In addition, maturity can be a hardly visible characteristic, mainly in smallsized seeds, as described by Queiroz and Loiola(13) to be 1-2 $\times 1-1.5 \mathrm{~mm}$ in trapezoid and honeycomb form. Nakagawa et al. ${ }^{(14)}$ reinforced the need for caution regarding the definition of physiological maturity of seeds with dormancy because of the risk of interpretation mistakes.

However, thermal shock proportionated by HW increased seedling emergence (Table 2), corroborating with Lima et al. ${ }^{(5)}$, although these authors evaluated germination in a controlled environment.

The data presented in this study and by Lima et al. ${ }^{(5)}$ highlight the necessity of dormancybreaking techniques for C. rotundifolia. The superiority of $\mathrm{HW}$ over $\mathrm{HA}$ and control (Table 2) as well as 6.7 percentage units above that of water immersion treatment could indicate this technique as appropriate for $C$. rotundifolia. Lima et al. ${ }^{(5)}$ also verified this same response of $C$. rotundifolia using $80^{\circ} \mathrm{C}$ water for 5 and $10 \mathrm{~s}$; Araújo et al.(15) found similar results for Chamaecrista debilis seeds treated with water at $100^{\circ} \mathrm{C}$ for 5,10 , and $15 \mathrm{~s}$.

Using sulfuric acid to break seed dormancy, Lima et al. ${ }^{(5)}$ also obtained no statistical difference; however, these authors observed up to $30 \%$ on germination with acid treatment. Some possible factors could justify the low results on emergence with $\mathrm{HA}$, such as insufficient exposure time of the tegument to the chemical attack or 
high chemical attack causing seed damage or providing a favorable environment for microorganism proliferation on seeds or both. The two last possibilities were observed by Dousseau et al. ${ }^{(16)}$ by studying the seeds of Zeyheria montana Mart.

According to Poletto et al. ${ }^{(17)}$, embryo contact with the moisture and microorganisms on the substrate, before starting the germinative process, can harm the germination of the seeds that were previously submitted to scarification. Microorganism development on tissue fissures of the seed may cause rotting and germination infeasibility. However, according to Footitt and Cohn ${ }^{(18)}$, there are commonly less germination problems under HA.

In contrast to the similarity obtained between control and EW on seedling emergence (Table 2), Adegas and Voll(19) observed high germination of Bidens pilosa treated with water immersion for $12 \mathrm{~h}$. Water absorption by seeds is directly correlated with time of exposure to water; however, the increase in absorption slows over time ${ }^{(20)}$. However, in this study, even $24 \mathrm{~h}$ was not enough to obtain significant effects on C. rotundifolia emergence.

Ineffective germination with water immersion treatment (Table 2) was also observed by Ferraz et al.(21) on Enterolobium contortisiliquum. However, these authors observed improvements in seed germination by the combination of scarification and water immersion. A similar mechanism can explain HW results. Thermal shock can have physical action on the seed tegument, followed by rehydration after $12 \mathrm{~h}$ of immersion in room-temperature water, accelerating the germination process.

According to Pacheco and Matos ${ }^{(22)}$, thermal stress may be responsible for the weakening of the integumentary tissue, providing cracks that allow the absorption of moisture to trigger the germination process. Contradicting this study, this treatment had no effect on Schizolobium amazonicum, in which dormancy was broken with mechanical scarification ${ }^{(23)}$.

Effects of dormancy-breaking techniques can vary with species. Although mechanical scarification was not evaluated in this study, it could increase seed susceptibility to damage, mostly in the smallest seeds, as described by Araújo et al.(15), who observed low efficiency of mechanical scarification on C. debilis.

The high value obtained for the emergence speed index in HW (Table 2) was probably a consequence of its positive effects on seedling emergence. The high dependency on endogenous stimulus and seed reserves from the other treatments, consequently, extending the time for germination and emergence, may have increased plant susceptibility. Low effect of dormancy-breaking techniques on mass production (Table 3) may be associated with the plant independence from seed reserves that may have been able to overcome the longer time required for germination in some treatments. However, higher aerial dry mass production in plants in the HW and HA treatments on sandy soil may be a consequence of the lightness and draining capacity of this type of soil.

Figueiró et al.(24) also verified positive effects of dormancy-breaking techniques on initial development of Schizolobium parahyba plants, and Martins et al.(25) observed 
better initial corn development in sandy soil. Moreover, Cruz et al.(2) already reported C. rotundifolia preference for sandy soils. Soil texture can influence processes such as compaction, water draining, and biological nitrogen fixation; thus, these results may be related to the soil physical characteristics (Table 4).

HA treatment associated with clayey soil can probably increase seed and plant susceptibility to damage or offer a propitious environmentfor microorganisms. According to Santos et al.(26), damage to seeds can affect germination, seedling emergence, and growth; however, damage intensity depends on the infecting pathogen.

High variability was also observed for the productive parameters of plants (high values of coefficient of variation). This variability among plants may be reduced in advanced growth stages; however, it is a performance resulting from a low degree of domestication or occurrence of crosses between domestic and wild species. According to Cavalho et al.(27), crosses between domestic and wild species may result in incompatibility and undesirable characteristics in the progeny. This increase in genetic diversity may lead to decreased yield, among other undesirable characteristics.

Treatments to break $C$. rotundifolia seed dormancy are required, aiming for better results in seedling emergence and initial development of plants. The search for maximum seed efficiency is important mostly because of the absence of commercial seeds ${ }^{(4)}$ and the laborious seed collection in the field.

In this context, HW could be a viable and accessible technique to break the dormancy of $C$. rotundifolia seeds, mostly for cultivation in soils with sandy texture. These results reinforce the importance of this species for Brazilian cattle breeding sited on sandy and low-fertility soils, highlighting the necessity of improved mechanisms to establish this species as a commercial crop.

\section{Conclusions}

Seedling emergence and some parameters of initial plant development of $C$. rotundifolia can be improved by dormancy-breaking techniques.

The association of dormancy-breaking techniques and soil types affected C. rotundifolia initial development. Positive effects were observed using HW and sandy soil, whereas negative effects were observed on the arrangement of HA and clayey soil.

Thermal shock using HW is recommended to break the dormancy of $C$. rotundifolia seeds to improve seedling emergence parameters.

\section{Conflict of interest}

The authors declare no conflict of interest. 
Dormancy-breaking treatments and soil types on Chamaecrista rotundifolia emergence and initial development Gomes $\rfloor \mathrm{N}$ et al.

\section{References}

1. Souza MS, Jardim AMRF, Araújo Júnior GNA, Silva JRI, Leite MLMV, Teixeira VI, Silva TGF. Ciclagem de nutrientes em ecossistemas de pastagens tropicais. Pubvet. 2018;12(5): 1-9. Available from: https://doi. org/10.22256/pubvet.v12n5a91.1-9.

2. Cruz ED, Camarão AP, Simão Neto M. Forage production and nutritive value of Chamaecrista rotundifolia (Persoon) Greene in the eastern Amazon Brazil. Pasturas Tropicales. 1999;21(3): 46-48. Available from: https://www.alice.cnptia.embrapa.br/bitstream/doc/373156/1/Vol21rev3ano99art10.pdf.

3. Abreu NL, Nascimento ALS, Pantoja RVL, Oliveira ISQ, Gomes JN, Faria LA. Épocas de corte na produtividade e valor proteico de forragem de Chamaecrista rotundifolia. Amazonian Journal of Agricultural and Environmental Sciences. 2020; 63. Available from: https://periodicos.ufra.edu.br/index.php/ajaes/ article/view/3256

4. Lopes OMN. Chamaecrista rotundifolia - Leguminosa para controle de mato e adubação verde do solo. Altamira EMBRAPA Amazônia Oriental - Recomendações técnicas N 11/2000 2001. Available from: https://ainfo.cnptia.embrapa.br/digital/bitstream/item/49380/1/fd160001.pdf.

5. Lima MP, Silva CC, Oliveira SRRS, Saraiva MP, Rodrigues AE, Pamplona VMS, Quadros BR. Superação de dormência e qualidade da luz na germinação de sementes de Chamaecrhysta rotundifolia (Pers.) Greene. Brazilian Journal of Development. 2020;6(7):44068-44078. Available from: https://doi.org/10.34117/ bjdv6n7-141.

6. Farias CCM, Lopes JC, Mengarda LHG, Maciel KS, Moraes CE. Biometria características físicas e absorção de água de sementes de Enterolobium maximum Ducke. Ciência Florestal. 2019;29(3):1241-1253. Available from: https://doi.org/10.5902/1980509814887.

7. Agra PFM, Guedes RS, Silva MLM, Souza VC, Andrade LA, Alves EU. Métodos para superação da dormência de sementes de Parkinsonia aculeata L. Semina: Ciências Agrárias. 2015;36(3):1191-1202. Available from: https://doi.org/10.5433/1679-0359.2015v36n3p1191

8. Queiroz P.C. Souza A.R. Santos T.M. Clemente J.M. Duarte A.R. Machado M.G. Superação de dormência de sementes de mucuna-preta. Humanidades \& Tecnologia em Revista (FINOM). 2019;18:68-75. Available from: http://revistas.icesp.br/index.php/FINOM Humanidade Tecnologia/article/viewFile/795/568.

9. Gautam AK, Shrivastava AK, Samaiya RK. Effect of aqueous fertilizer on soil moisture content depth of seeding and seedling emergence for wheat. International Journal of Agricultural Science and Research. 2017;7(3):241-246. Available from: https://www.researchgate.net/publication/333372377 EFFECT OF_AQUEOUS_FERTILIZER_ON_SOIL_MOISTURE_CONTENT_DEPTH_OF_SEEDING_AND_SEEDLING_ EMERGENCE FOR WHEAT

10. Labouriau LG, Valadares MEB. On the germination of seeds Calotropis procera (Ait.) Ait.f. In: ANAIS DA ACADEMIA BRASILEIRA DE CIÊNCIAS. Embrapa Cerrados. 1976;48:263-284.

11. Maguire JD. Speed of germination and in selection and evaluation for seedling emergence and vigour. Crop Science. 1962;2:176-177.

12. Ribeiro IFN, Carvalho CA, Januário JL, Prado LS, Oliveira MCR, Oliveira RFS. Emergência de plântulas de jutaí (Hymenaea oblongifolia Huber. Fabaceae) em diferentes substratos. Scientia Naturalis. 2020;2(1):96101. Available from: https://periodicos.ufac.br/index.php/SciNat/article/view/3508

13. Queiroz RT, Loiola MIB. O gênero Chamaecrista Moench (Caesalpinioideae) em áreas do entorno do Parque Estadual das Dunas de Natal Rio Grande do Norte Brasil. Hoehnea. 2009;36(4):725-736. Available from: https://doi.org/10.1590/S2236-89062009000400011

14. Nakagawa J, Zucareli C, Cavariani C, Gaspar-Oliveira C. Maturação de sementes de mucuna- 
Dormancy-breaking treatments and soil types on Chamaecrista rotundifolia emergence and initial development Gomes J N et al.

preta. Bioscience Journal. 2007;23(1):41-47. Available from: http://www.seer.ufu.br/index.php/ biosciencejournal/article/view/6381

15. Araújo JEVL, Nery MC, Mendonça Filho CV, Pires RMO, Nery FC, Fialho CMT. Germinação de sementes em função do tratamento pré-germinativo de Chamaecrista debilis (Vogel) Irwin e Barneby. Ciência Agrícola. 2017;15(1):1-7. Available from: http://repositorio.ufla.br/jspui/handle/1/30183

16. Dousseau S, Alvarenga AA, Castro EM, Arantes LO, Nery FC. Superação de dormência em sementes de Zeyheria Montana Mart. Ciência e Agrotecnologia. 2007;31:1744-1748. Available from: https://doi. org/10.1590/S1413-70542007000600021

17. Poletto T, Muniz MFB, Poletto I, Baggiotto C. Métodos de superação de dormência da semente de nogueira-pecã Carya illinoinensis (Wangenh.) K. Koch. Revista Árvore. 2015;39(6):1111-1118. Available from: https://doi.org/10.1590/0100-67622015000600014.

18. Footitt S, Cohn MA. Seed dormancy in red rice VIII. Embryo acidification during dormancy-breacking and subsequent germination. Plant Physiology. 1992;100:1196-1202. Available from: https://doi. org/10.1104/pp.100.3.1196.

19. Adegas FS, Voll E. Embebição e germinação de sementes de picão-preto (Bidens pilosa). Planta Daninha. 2003;21:21-25. Available from: https://doi.org/10.1590/S0100-83582003000100003

20. Ferreira G, Guimarães VF, Pinho SZ, Oliveira MC, Richart A, Braga JF, Dias GB. Curva de absorção de água em sementes de atemóia (Annona cherimola mill. x Annona squamosa L.) Cv. Gefner. Revista Brasileira de Fruticultura. 2006;28:121-124. Available from: https://doi.org/10.1590/S0100-29452006000100033.

21. Ferraz D, Ramalho WP, Vale LSR. Methods for overcoming dormancy and seed storage of Enterolobium contortisiliquum. Acta Scientiarum Agronomy. 2019;41:e42602. Available from: https://doi.org/10.4025/ actasciagron.v41i1.42602

22. Pacheco MV, Matos VP. Método para superação de dormência tegumentar em sementes de Apeiba tibourbou Aubl. Revista Brasileira de Ciências Agrárias. 2009;4(1):62-66. Available from: https://doi. org/10.5039/agraria.v4i1a10

23. Carvalho MBF, Araujo MER, Mendonça AP, Chavez MS, Gutierrez KL, Ruiz FJP, Mocho AP. Métodos de superação de dormência da Schizolobium amazonicum Huber ex Ducke. Brazilian Journal of Animal and Environmental. 2019;2(1):490-500._Available from: https://www.brazilianjournals.com/index.php/BJAER/ article/view/1436/1323

24. Figueiró CG, Macedo FF, Fialho LF, Silva CMS, Cândido WL. Efeito do recipiente e do método de superação de dormência no crescimento de mudas de Schizolobium parahyba (Vell.) S.F. Blake. Enciclopédia Biosfera. 2017;14(25):490-497. Available from: https://www.conhecer.org.br/enciclop/2017a/agrar/efeito\%20 do\%20recipiente.pdf

25. Martins AG, Rampim L, Rosset JS, Prior M, Coppo JC. Aplicação de bioestimulante em sementes de milho cultivado em solos de diferentes texturas. Scientia Agraria Paranaensis. 2016;15(4):440-445. Available from: https://doi.org/10.18188/sap.v15i4.13028

26. Santos FEM, Sobrosa RC, Costa IFD, Corder MPM. Detecção de fungos patogênicos em sementes de acácia-negra (Acacia mearnsii De Wild). Ciência Florestal. 2001;11: 13-20. Available from: https://doi. org/10.5902/19805098491.

27. Carvalho JMFC, Silva MMA, Medeiros MFL. Perda e Conservação dos Recursos Genéticos Vegetais. Centro Nacional de Pesquisa de Algodão Campina Grande, PB - Documentos 221 2009. https://www. infoteca.cnptia.embrapa.br/infoteca/bitstream/doc/656849/1/DOC221.PDF 